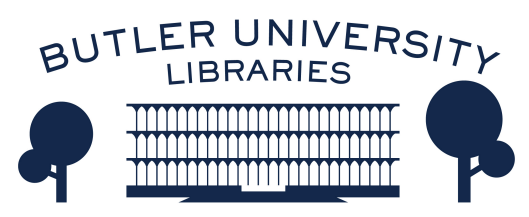

Journal of Hindu-Christian Studies

Volume 23

Article 24

January 2010

\title{
Book Review: "Jesus in the Lotus: The Mystical Doorway between Christianity and Yogic Spirituality"
}

Bradley Malkovsky

Follow this and additional works at: https://digitalcommons.butler.edu/jhcs

Part of the Religion Commons

\section{Recommended Citation}

Malkovsky, Bradley (2010) "Book Review: "Jesus in the Lotus: The Mystical Doorway between Christianity and Yogic Spirituality"," Journal of Hindu-Christian Studies: Vol. 23, Article 24.

Available at: https://doi.org/10.7825/2164-6279.1476

The Journal of Hindu-Christian Studies is a publication of the Society for Hindu-Christian Studies. The digital version is made available by Digital Commons @ Butler University. For questions about the Journal or the Society, please contact cbauman@butler.edu. For more information about Digital Commons @ Butler University, please contact digitalscholarship@butler.edu. 
transformation that dialogue with an other engenders with the ontology of the self in Gaudiya Vaisnavism. Her comparison reveals how both traditions regard difference as fundamental to dialogue and full engagement with difference as the chief condition for transformation.

Arvind Sharma's careful responses to each of the papers is a nice addition to the volume, expanding the insights of each of the essays and demonstrating a cohesiveness to the volume that may not be evident on reading the individual essays themselves.

Hermeneutics and Hindu Thought takes no one paradigm for how a cross-cultural hermeneutics might or should take place as its standard. Its authors demonstrate, rather, that there is much promise in simply posing the question implied by the conjunction "and" in the book's title. That is to say, when one considers the range of projects that thinking about hermeneutics and Hindu thought together might generate, it is clear that there is a great deal of work that lies ahead as we begin to appreciate the tremendous resources for cross-cultural understanding that Indic traditions contain.

Brian K. Pennington

Maryville College

\section{Jesus in the Lotus: The Mystical Doorway between Christianity and Yogic Spirituality. Russill Paul. Novato, California: New World Library, 2009, 233 pp.}

Anyone interested in studying yoga theory and practice, its history from the time of Patañjali to today, its seeming endless variety of contemporary expressions and schools, will be hard pressed to keep up with the scholarly literature. The same cannot be said of the literature on the Christian encounter with yoga. Serious scholarship addressing the integration of yoga practice (especially aștānga yoga) and yoga philosophy into Christian spiritual praxis and theology is surprisingly rare, especially given the fact that thousands, perhaps millions of Christians today have taken up the practice of yoga. What is less rare are the many one-sided appraisals that either condemn or extol the merging of yoga and Christianity. Too often modern opinion treats yoga as a monolithic entity, often unaware of the complexity of yoga and its history. This simplistic approach, of course, makes it all too easy for Christian authors to argue their widely divergent positions.

Jesus in the Lotus: The Mystical Doorway between Christianity and Yogic Spirituality takes up the issue of yoga and Christianity in earnest fashion, but it is only partly successful in its approach, as it falls prey at times to a shifting understanding of what exactly yoga is. The author, Russill Paul, is a professional musician turned spiritual teacher and writer. Born and raised in India, he became a Benedictine monk under Bede Griffiths (d. 1993), the well-known Catholic monk and spiritual writer. After living five years at Father Bede's Saccidananda Ashram he left monastic life and carried to the West his master's legacy of "interspirituality" and his teaching about the complementarity of religions. For the past twenty years Paul has conducted numerous spirituality workshops and retreats, mostly in the U.S, as well as led spiritual pilgrimages back to his Indian homeland.

The author passionately advocates the incorporation of yoga into Christian praxis, for, he says, contemporary Christianity needs yoga to recover its mystical depth. Christians who practice yoga can "deepen their connection to God, other human beings, and creation as a whole." (5) Yoga can remedy the widespread tendency among Western Christians to think of divine transcendence as God's remote separation from creation. 'Yoga can restore a more nondualistic understanding of the divine-human and divine-world relationship, and it also can serve to reintroduce Christians to the sacredness of the body (30). What is remarkable about these 
broad assertions is that they do not distinguish between, on the one hand, the classical Patañjala approach to God and the human body and, on the other hand, widespread contemporary yoga understandings. Yoga today, especially as practiced in the West and therefore quite unlike Patañjali's Yoga-Sütra, often tends to treat mystical experience as "God"-experience and to regard life in the body as something to be valued rather than as something to be transcended and abandoned. The thoroughgoing anthropological dualism of classical yoga philosophy and its lack of an omnipresent Absolute are largely unknown to today's Western practitioners. It is therefore difficult to say what "yoga" offers Christianity, since "yoga" is so many things.

Roughly the first half of the book presents what might be called the quantification and manipulation of the spiritual. Judged from the perspective of traditional Christian spirituality the author gives excessive importance to mental states and techniques and changes in himself and his body. He places much emphasis on his trances and his spiritual accomplishments. I did this, and this happened, and then I did that, and that happened. He describes out of body experiences, electrical energy entering his feet and working its way up to his head, of "sound translating into color," of seeing "ribbons of golden light curl round the temple and come toward me, accompanied by a dull, thudding sound in the distance" (126-127). The personal God all but disappears in these pages as full attention is given to the metamorphosis and topography of human awareness. We do not yet hear about perfect abandonment to divine love or to the divine will, so characteristic of the Christian mystical tradition. And yet these pages are valuable in giving testimony to the very real effects of Tantra, Kundalini Yoga, and various kinds of meditation. At this point it is clear that the "Yogic Spirituality" of the book's title refers to a great number of eastern techniques and spiritualities. This is "yoga" understood in a very broad sense, i.e. as a collection of eastern spiritual techniques and disciplines; it is not just the discipline of asțanga yoga.

It is precisely at this point in the book (ch. 5: "Charting a Path") that the author, writing frankly and autobiographically, surprises us by describing his growing awareness of the danger of this self-preoccupation that often enough follows from Western yoga discipline. These pages describe masterfully the possibilities of self-deception in the spiritual life, of the prideful ego reasserting and rebuilding itself even after strenuous disciplines of self-denial. When all of the chapters are taken together it is clear that one of the strengths of this book is the author's frequent reference to his own personal experience as both a yogi and a Christian.

It was the rediscovery of the divine as person that changed everything for the author. Paul was inspired by the prayer of Father Bede and by his reading of Brother Lawrence's (17th c.) spiritual classic, The Practice of the Presence of God. He realized that his desire for experiences and even enlightenment had made him forgetful of the Beloved. "Engrossed in learning to control mind, breath, and body," he writes, "I had forgotten to seek the Divine as a person, as a being whom I could interact with ... . the mystery of God was not truly alive within the field of my consciousness" (145). He had not yet entered into an "authentic relationship" with God. (128)

And so while he extols the benefits of yoga practice for Christian spirituality the author also wants to show the value of Christianity for those yoga practitioners and teachers who are frequently dismissive of the religion for being spiritually shallow and inferior to yoga.

$\mathrm{He}$ feels that Christianity's gift is the experience of being deeply and unconditionally loved by -God. (164) It also offers hope to the poor and marginalized of society, and it gives meaning and value to every individual human being, both now and in the transformed life to come. Paul feels that yoga practitioners could learn from the message of Jesus and his followers to be more attentive to human relationships and human community as a legitimate sphere of spiritual development.

In one of his concluding remarks the author notes that the United States has become an especially auspicious land for dialogue between Christianity and other religions. In the contemporary movement toward interspirituality the U.S., he says, is "the world's laboratory." 
(182) Its openness to learn from other religions helps explain why "so many Eastern teachers have found such fulfillment and appreciation in this country." (185) In addition, such American values as fairness and accountability have subjected Eastern .masters and their teachings to a necessary critique. This give-and-take in the spiritual life, the willingness to respond to the challenge of the other, is a process that must continue to be nurtured, for the benefit and spiritual growth of all. Paul's book, despite its flaws, offers a balanced, refreshing, and valuable perspective that is rare in the literature on the contemporary engagement of yoga and Christianity.

Bradley Malkovsky

University of Notre Dame 